\title{
Prosedur Pengelolaan Produk Deposito pada PT. BPRS Amanah Bangsa
}

\author{
Calen \\ Sekolah Tinggi Akuntansi Dan Manajemen \\ Indonesia \\ calen.chan88@gmail.com
}

Asmawati Halilah Damanik

Sekolah Tinggi Akuntansi Dan Manajemen

Indonesia

asmawatidamanik@gmail.com

\author{
Christopher Agustian \\ Sekolah Tinggi Akuntansi Dan Manajemen \\ Indonesia \\ chrstopheragustian121@gmail.com
}

\author{
Arwin Tannuary \\ Sekolah Tinggi Akuntansi Dan Manajemen \\ Indonesia \\ arwintannuary18@gmail.com
}

\begin{abstract}
Abstrak
The Amanah Bangsa Islamic Bank Financing Bank exists and grows as a bank that is able to provide banking services based on sharia principles. As a community facility, BPRS Amanah Bangsa offers a time deposit product or often referred to as Time Deposit. Deposits at BPRS Amanah Bangsa are savings using a mudharabah contract, where the customer is called sahibul maal while the bank is the mudharib. Funds in deposits are guaranteed by the government through the Deposit Insurance Corporation (LPS) with certain conditions. Usually Deposit products have a storage period of 1, 3, 6, or 12 months according to the wishes of the customer. Deposits can also be renewed automatically when they are due until the owner withdraws the deposit. The mudharabah contract application in time deposits products at BPRS Amanah Bangsa is a contract whose management meets the mudharib (bank) responsibilities and the customer is obliged to follow the provisions given by the bank.
\end{abstract}

Keyword : Islamic Bank, Financing, Deposit

\section{PENDAHULUAN}

Bank Pembiayaan Rakyat Syariah Amanah Bangsa hadir dan tumbuh sebagai bank yang mampu memberikan sebuah layanan perbankan berdasarkan prinsip syari'ah. Sebagai sarana masyarakat, BPRS Amanah Bangsa menawarkan produk berupa tabungan berjangka atau sering disebut Deposito. Deposito pada BPRS Amanah Bangsa merupakan tabungan dengan menggunakan akad mudharabah, dimana nasabah disebut sahibul maal sedangkan pihak bank sebagai mudharib. Dana yang ada didalam deposito dijamin oleh pemerintah melalui Lembaga Penjamin Simpanan (LPS) dengan persyaratan tertentu. Biasanya produk Deposito mempunyai jangka waktu penympanan yaitu 1,3 ,
6, atau 12 bulan sesuai dengan keinginan dari nasabah. Deposito juga dapat diperpanjang secara otomatis ketika telah jatuh tempo sampai pemiliknya mencairkan deposito.

Pada saat penulis melakukan Penelitian, penulis mengikuti alur akad yang dilakukan nasabah secara langsung sehingga penulis dapat mengetahui secara persis alur pembukaan rekening Deposito pada BPRS Amanah Bangsa. Peneliti juga menemukan bahwa pihak BPRS kurang memberikan informasi atau kurang transparansi kepada para nasabah mengenai biaya yang dikenakan pada nasabah yang memenuhi syarat.

Untuk itu, karena peneliti telah mengamati alur akad yang dilakukan oleh nasabah dan BPRS 
Amanah bangsa dan menemukan bahwa pihak BPRS kurang memberikan informasi mengenai produk Deposito, maka judul dari Penelitian ini adalah PROSEDUR PENGELOLAAN PRODUK DEPOSITO PADA BPRS AMANAH BANGSA.

\section{Ruang Lingkup}

Pada penelitian ini, penulis akan membahas mengenai prosedur dan alur akad pembukaan rekening Deposito mulai dari nasabah datang dan sampai dengan selesai. Dalam laporan ini penulis juga akan membahas tentang dokumen yang harus dipenuhi untuk pembukaan rekening Deposito. Serta biaya yang dikenakan pada nasabah jika nasabah tersebut memenuhi syarat yang telah ditentukan oleh BPRS Amanah Bangsa. Penulis juga membahas tentang nisbah yang diberikan kepanda nasabah serta jumlah bagi hasil yang diterima setelah adanya pemotongan yang telah dikenakan oleh BPRS Amanah Bangsa. Juga bagaimana pihak BPRS Amanah Bangsa mempromosikan produk Deposito sehingga dapat menarik nasabah untuk menginfestasikan dananya pada BPRS Amanah Bangsa.

\section{LANDASAN TEORI BPR Syari'ah}

Menurut OJK Bank Perkreditan Rakyat (BPR) adalah Bank yang melaksanakan kegiatan usaha secara konvensional atau berdasarkan prinsip syariah, yang dalam kegiatannya tidak memberikan jasa dalam lalu lintas pembayaran. Dimana kegiatan BPR jauh lebih sempit jika dibandingkan dengan kegiatan bank umum karena BPR dilarang menerima simpanan giro, kegiatan valas, dan perasuransian. Sedangkan Bank Perkreditan Rakyat Syariah (BPRS) adalah bank yang melaksanakan kegiatan usaha berdasarkan prinsip syariah dalam kegiatannya tidak memberikan jasa dalam lalu lintas pembayaran.

BPRS berdiri berdasarkan Undang-undang No 7 Tahun 1992 tentang Perbankan dan Peraturan Pemerintah (PP) No 72 tahun 1992 mengenai Bank Berdasarkan Prinsip Bagi Hasil.
Namun setelah terjadi perubahan BPRS diatur dalam Undang-undang No 10 Tahun 1998.

Untuk kegiatannya sendiri BPRS yang melakukan kegiatan usaha berdasarkan prinsip syariah selanjutnya diatur menurut Surat Keputusan Direktur Bank Indonesia No. 32/36/KEP/DIR/1999 tanggal 12 Mei 1999 tentang Bank Perkreditan Rakyat Berdasarkan Prinsip Syariah.

Seperti lembaga keuangan lainnya, BPRS juga melakukan kegiatan yang berkaitan dengan menghimpun dana dan menyalurkan kredit. Hal ini tercantum pada Undang-undang perbankan NO 10 tahun 1998. Namun, tidak seperti Bank Umum Syariah ataupun Unit Usaha Syariah, ada beberapa kegiatan yang dilarang dilakukan BPRS menurut Undang-undang No. 17 pasal 14 tahun 1992.

\section{Kegiatan BPRS yang diperbolehkan :}

a. Menghimpun dana dari masyarakat dalam bentuk simpanan berupa deposito berjangka, tabungan dan atau bentuk lainnya yang dipersamakan dengan itu.

b.Memberikan kredit.

c.Menyediakan pembiayaan dan penempatan dana berdasarkan prinsip syariah sesuai dengan ketentuan yang ditetapkan oleh Bank Indonesia. d.Menempatkan dananya dalam bentuk Sertifikat Bank Indonesia, deposito berjangka, sertifikat deposito, dan atau tabungan pada bank lain

\section{Kegiatan BPRS yang dilarang :}

a.Menerima simpanan dalam bentuk giro dan ikut serta dalam lalu lintas pembayaran b.Melakukan kegiatan usaha dalam bentuk valuta asing c.Melakukan penyertaan modal d.Melakukan usaha perasuransian e.Melakukan usaha lain di luar kegiatan usaha sebagaimana disebutkan pada kegiatan usaha yang boleh dilakukan oleh BPRS.

Berdasarkan POJK.03/2016, badan hukum usaha Bank Pembiayaan Syariah wajib berbentuk Perseroan Terbatas (PT.), pendirian BPRS hanya dapat dididrikan dan/atau dimiliki oleh pertama warga negara Indonesia. Kedua, pemerintah 
daerah. Ketiga, kerjasama kedua belah pihak sebagaimana dimaksudkan dalam poin pertama dan kedua.

Dari segi syarat minimum permodalan yang disetor oleh pendirian BPRS, dikelompokkan menjadi empat kelompok berdasarkan zona pendirian BPRS. Modal yang disetor untuk mendirikan BPRS paling sedikit:

1.Rp 12.000.000.000,00 (dua belas milyar rupiah), bagiBPRS yang didirikan di zona 1 ;

2.Rp 7.000.000.000,00 (tujuh milyar rupiah), bagi BPRS yang dididirikan di zona 2;

3.Rp 5.000.000.000,00 (lima milyar rupiah), bagi BPRS yang didirikan di zona 3; dan

4.Rp 3.500.000.000,00 (tiga milyar tiga ratus juta rupiah), bagi BPRS yang didirikan di zona 4 .

\section{Bentuk Organisasi BPRS}

Bentuk organisasi BPRS berdasarkan POJK.03/2016 mencakup Direksi, Dewan Komisaris, dan anggota Dewan Pengawas Syari'ah (DPS). Pengangkatan Direksi, Komisaris dan DPS dilakukan berdasarkan Rapat Umum Pemegang Saham (RUPS) dan berlaku efektif setelah mendapatkan izin dai OJK.

\section{Direksi}

Tugas dan fungsi Direksi antara lain adalah menyusun perencanaan, melakukan koordinasi dan pengawasan terhadap seluruh kegiatan BPRS. Posisi Direksi sebagai pelaksana managemen berdasarkan kebijakan umum dari Dewan Komisaris. Direksi bertanggungjawab terhadap operasional BPRS agar lebaga tetap sehat dan tumbuh secara berkelanjutan. Seorang Direksi dilarang merangkap jabatan sebagai anggota Komisaris atau jabatan eksekutif di lembaga perbankan, perusahaan, dan lembaga lain. Anggota direksi berhenti apabila masa jabatan sudah berakhir atau meninggal dunia. Direksi juga bisa diberhentikan berdasarkan RUPS ketika ditemukan tindakan Direksi yang dapat merugikan RUPS, alasan sendiri atau tidak melaksanakan tugas sebagai mana semestinya.

\section{Dewan Komisaris}

Tugas utaa Dewan Komisaris adalah menetapkan kebijakan umum, pengawasan, pengendalian dan pemninaan terhadap BPRS. Dalam menjalankan tugasnya, Dewan Komisaris menyusun tata cara pengawasan dan pengelolaan BPRS, mengawasi kepengurusan, menetapkan kebijakan anggaran dan keuangan BPRS serta membina dan mengembangkan BPRS. Dewan Komisaris dilarang memiliki hubungan kekeluargaan dengan anggota Dewan Komisaris lain, atau denagn Direksi untuk menjaga integritas Dewan Komisaris. Pemberhentian Dewan Komisaris kurang lebih sama dengan Direksi selain habis masa periode atau meninggal, pemberhentian Komisaris berdasarkan hasil keputusan RUPS.

\section{Dewan Pengawas Syariah}

BPRS wajib memiliki Dewan Pengawas Syariah (DPS) yang bekerja di kantor pusat minimal satu orang dan maksimal tiga orang. Tugas dan fungsi utama dari DPS adalah memastikan dan mengawasioperasional kegiatan usaha dari BPRS berdasarkan ketentuan syari'ah yang diatur dalam fatwa DSN-MUI. Pemberhentian anggota DPS berdasarkan hasilRUPS, habis masa periode atau meninggal dunia.

\section{Deposito}

Deposito adalah simpanan yang penarikannya hanya dapat dilakukan pada waktu tertentu berdasarkan perjanjian antara nasabah dan juga pihak bank. Tujuan dan manfaat deposito syari'ah ini dapat dilihat dari kepentingan bank dan juga dari kepentingan nasabah. Dari aspek bank itu sendiri ada beberapa tujuan dan manfaat yang diperoleh antara lain: sumber pendanaan bank baik dalam rupiah maupun valuta asing dengan jangka waktu tertentu yang lebih lama dan fluktuasi dana yang relatif rendah. Sedangkan untuk nasabah manfaat yang diteima adalah alternatif investasi yang memberikan keuntungan dalam bentuk bagi hasil.

Dalam perbankan syari'ah akad untuk jenis produk deposito adalah Mudharabah, yaitu transaksi penanaman dana dari pemilik dana (shahibul maal) kepada pengelola dana (mudharib) untuk melakukan kegiatan usaha 
tertentu yang sesuai dengan pembagian hasil usaha antara kedua belah pihak berdasarkan nisbah yang telah disepakati sebelumnya. Mudharabah terdiri dari mudharabah muthlaqah, muqayyadah, dan musytarakan.

Pada prinsipnya dalam penyaluran mudharabah tidak ada jaminan, namun agar pengelolan dana tidak melakukan penyimpangan maka pemilik dana dapat meminta jaminan dari pengelola dana atau pihak ketiga. Jaminan ini hanya dapat dicairkan apabila pengelola dana terbukti melakukan pelanggaran terhadap hal-hal yang telah disepakati bersama dalam akad. Pengembalian dana mudharabah dapat dilakukan secara bertahap bersamaan dengan distribusi bagi hasil atau secara total pada saat akad mudharabah diakhiri.

Adapun mekanisme yang digunakan pada produk deposito ini antara lain :

a. Bank bertindak sebagai pengelola dan (mudharib) dan nasabah beertindak sebagai pemilik dana (shahibul maal);

b. Pengelolaan dana oleh bank dapat dilakukan sesuai batasa-batasan yang ditetapkan oleh pemilik dana (mudharabah muqayyah) atau dilakuakn dengan batasan-batasan dari pemilik dana (mudharabah mutlawah);

c. Dalam akad mudharabah muqayyah harus dinyatakan secara jelas syarat-syarat dan batasan tertentu yang ditentukan oleh nasabah;

d. Pembagian keuntungan dinyatakan dalam bentuk nisbah yang disepakati

e. Penarikan dana oleh nasabah hanya dapat dilakukan sesuai waktu yang disepakati;

f. Bank dapat membebankan kepada nasabah biaya administrasi berupa biaya-biaya yang terkait langsing dengan biaya pengelolaan rekening antara lain biaya materai, cetak laporan tranasaksi dan saldo rekening, pembukaan dan penutupan rekening; dan

g. Bank tidak diperbolehkan mengurangi bagian keuntungan nasabah tanpa persetujuan nasabah yang bersangkutan.

\section{METODE PENELITIAN Teknik Pengumpulan Data}

Teknik yang digunakan dalam pengumpulan data adalah sebagai berikut:

\section{Observasi}

Dengan dilakukannya pengamatan langsung terhadap pembukaan rekening Deposito dan akad yang dilakukan dan juga mengamati pengelolaan data nasabah yang akan membuka rekening Deposito.

\section{Wawancara}

Dengan dilakukannya tanya jawab secara langsung dengan karyawan yang bekerja pada bidang yang bersangkutan dengan produk Deposito. Dengan dilakukannya tenik ini dapat memungkinkan untuk menggali informasi yang diperlukan.

\section{Teknik Analisis}

Teknik analisis yang digunakan dalam penelitian ini adalah teknik Miles dan Huberman, yaitu reduksi data, penyajian data, penarikan kesimpulan/verifikasi.

\section{HASIL DAN PEMBAHASAN Prosedur pembukaan rekening Deposito}

Pada saat nasabah datang terlebih dahulu ditanyakan ada keperluan apa kemudian nasabah mengatakan ingin membuka rekening Deposito, kemudian nasabah akan diarahkan pada bagian Customer Service (CS). Pada bagian CS nasabah ditanya kembali ada keperluan, setelah itu CS mulai bertanya mengenai jumlah uang yang akan dimasukkan kedalam rekening deposito nantinya. Lalu nasabah dimintai keterangan data berupa fotocopy Kartu Tanda Penduduk (KTP), Kartu Keluarga (KK) untuk kelengkapan data diri. CS kemudian mengeluarkan dan mengisi form permohonan pembukaan deposito, kemudian CS memasukkan data nasabah sesuai data diri nasabah. CS melakukan input data nasabah dalam system untuk pembukaan rekening deposito dan menetapkan nomor rekening deposito yang diperoleh dalam system dan menuliskannya pada slip setoran.Mengisis slip setoran dengan jumlah uang yang akan dimasukkana dalam deposito.

Setelah selesai nasabah diminta untuk membubuhkan tanda tangan dengan diarahkan oleh CS. CS menyerahkan slip setoran pada 
bagian Teller, kemudian teller menghitung jumlah uang dan memeriksa keasliannya dan menginput setoran ke system berdasarkan nomor rekening pada slip setoran. Setelah itu CS akan meminta agar nasabah menunggu sebentar untuk pencetakan bilyet, lalu nasabah akan diminta kembali tanda tangan pada bilyet dan CS membubuhkan cap stempel pada bilyet. Kemudian nasabah diminta membawa bilyet yang asli sebagai bukti dan bilyet yang telah dicopy ada pada bank sebagai pertinggal data. Serta membawa lembar tembusan slip setoran ke nasabah.

\section{Perkembangan produk Deposito \\ a. Promosi Produk Deposito}

Pada saat mahasiswa melakukan praktik kerja lapangan pada BPRS Amanah Bangsa, mahasiswa mengamati bahwa nasabah yang datang untuk menginfestasikan dananya pada BPRS Amanah Bangsa pada 1 bulan kurang lebih 10 nasabah, hal ini menunjukkan adanya sedikit peningkatan dalam produk Deposito. Mengingat bahwa pihak BPRS Amanah Bangsa kurang mempromosikan produk Deposito sehingga peningkatan pada produk Deposito tidak maksimal atau tidak sesuai target. Hal itu disebabkan pihak BPRS Amanah Bangsa tidak memasang pamflet atau spanduk mengenai produk Deposito yang akan menarik nasabah untuk menginfestasikan dananya, tetapi pihak dari BPRS Amanah Bangsa membuat brosur yang menjelaskan tentang produk Deposito akan tetapi brosur tersebut hanya menjadi pajangan dan tidak disebarkan atau diberikan pada setiap nasabah yang datang. Dan letak brosur yang tidak strategis sehingga sulit untuk nasabah melihat adanya brosur.

\section{b. Pelayanan yang Diberikan Kepada Nasabah}

Pelayanan yang diberikan oleh Customer Service (CS) pada BPRS Amanah Bangsa kurang memuaskan, karena pada saat nasabah datang CS kurang antusias dalam melayani. Serta dalam hal informasi, CS kurang memberikan informasi yang lengkap atau tidak transparansi kepada nasabah mengenai jumlah bagi hasil yang diterima dan mengenai pembagian nisbah serta biaya yang akan dikenakan pada nasabah yang memenuhin syarat. Mengingat nasabah yang datang ingin membuka rekening Deposito kebanyakan lanjut usia dan kurang mengetahui produk Deposito, karena itu CS haruslah memberitahukan informasi yang lengkap kepada nasabah.

\section{Perkembangan produk Deposito}

Pada saat tanggal jatuh tempo atau pencairan deposito nasabah hanya perlu membawa data diri seperti KTP ataupun KK beserta bilyet deposito, nasabah akan langsung diarahkan pada bagian CS, kemudian CS akan memproses dan menyiapkan slip pencairan deposito dan nasabah diminta untuk menandatangani slip pencairan tersebut. Jika pencairan yang akan dilakukan oleh nasabah melebihi Rp. 25.000.000,- maka, nasabah terlebih dahulu harus mengkonfirmasi kepada pihak BPRS. Dan jika nasabah lupa mengambil atau tidak mengambil uangnya pada saat tanggal jatuh tempo maka pihak BPRS menggunakan perpanjangan otomatis (Automatic Roll Over/ ARO).

\section{Pelayanan yang Diberikan Customer Service}

Deposito merupakan simpanan yang penarikannya hanya dapat dilakukan pada waktu tertentu berdasarkan perjanjian antara nasabah dan bank. Deposito adalah salah satu produk BPRS Amanah Bangsa yang dirancang untuk memenuhi kebutuhan investasi secara syari'ah. Maka dari itu, pelayanan yang diberikan kepada nasabah haruslah baik. Muharabah adalah kerjasama antara dua pihak dimana pihak pertama menyediakan seluruh modal dan pihak lain menjadi pengelola. Pelayanan secara etimologis dalam KBBI yaitu usaha melayani kebutuhan seseorang, maka dari itu CS haruslah memberikan pelayanan sesuai SOP yang berlaku agar nasabah yang merasa puas akan menyampaikan kepada orang lain sehingga orang lain akan tertarik menggunakan produk karena pelayanan yang baik pula. 
Pada pembukaan rekening deposito, ada beberapa syarat yang harus dipenuhi oleh calon nasabah, yaitu :

a. Saldo minimal pembukaan rekening deposito Rp. 1.000.000,-

b. Menyerahkan fotocopy identitas diri seperti KTP dan KK yang masih berlaku.

c. Dokumen atau persyaratan lain sesuai yang diatur dalam kebijakan umum operasi maupun syarat dan ketentuan umum pembukaan rekening.

Kemudian CS kemudian mengeluarkan dan mengisi form permohonan pembukaan deposito, kemudian CS memasukkan data nasabah sesuai data diri nasabah.CS melakukan input data nasabah dalam system untuk pembukaan rekening deposito dan menetapkan nomor rekening deposito yang diperoleh dalam system dan menuliskannya pada slip setoran. Mengisis slip setoran dengan jumlah uang yang akan dimasukkana dalam deposito. Setelah selesai nasabah diminta untuk membubuhkan tanda tangan dengan diarahkan oleh CS.

CS menyerahkan slip setoran pada bagian Teller, kemudian teller menghitung jumlah uang dan memeriksa keasliannya dan menginput setoran ke sistem berdasarkan nomor rekening pada slip setoran. Setelah itu CS akan meminta agar nasabah menunggu sebentar untuk pencetakan bilyet, lalu nasabah akan diminta kembali tanda tangan pada bilyet dan CS membubuhkan cap stempel pada bilyet. Kemudian nasabah diminta membawa bilyet yang asli sebagai bukti dan bilyet yang telah dicopy ada pada bank sebagai pertinggal data. Serta membawa lembar tembusan slip setoran ke nasabah. Setelah nasabah mengikuti alur pembukaan deposito, maka nasabah sudah selesai membuka rekening deposito yang diinginkan.

Selama penulis melakukan penelitian, penulis menemukan bahwa kurangnya informasi atau tidak detailnya informasi yang diberikan terhadap nasabah yang akan membuka rekening deposito yakni tentang pembagian hasil antara bank dan nasabah, jumlah pembagian hasil yang akan didapat nasabah setiap bulan dan adanya biaya yang dibebankan pada nasabah dengan syarat tertentu. Karena mengingat nasabah yang membuka deposito adalah bagian penting dalam perputaran uang diBank, seharusnya CS memberikan pelayanan yang terbaik dan transparan sesuai SOP yang berlaku.

Dalam hal ini, seharusnya pihak bank lebih menerangkan atau menginformasikan lebih detail tentang produk deposito, sehingga nasabah yang ingin membuka rekening deposito lebih mengerti jumlah bagi hasil yang akan diterima nasabah, juga pencairan yang dilakukan. Pihak BPRS seharusnya lebih memberikan pengawasan kepada karyawan terutama pada bagian CS agar lebih meningkatkan kinerjanya. Pihak BPRS juga dapat memberikan pelatihan mengenai produk deposito agar karyawan lebih mengerti dalam menjalannkan pekerjaanya dan dapat memberikan pelayanan dengan baik terutama dalam hal produk deposito.

\section{Perhitungan Bagi Hasil}

Jika nasabah ingin membuka rekening deposito, maka seharusnya calon nasabah haruslah mengetahui tentang jumlah bagi hasil yang nasabah terima pada setiap bulannya, tetapi BPRS Amanah Bangsa cenderung tidak menginformasikan jumlah bagi hasil tersebut. Jika seperti ini, nasabah cenderung tidak mengetahui tentang keuntungan yang nasabah terima.

Adapun perhitungan jumlah bagi hasil yang diterima nasabah harus diikuti dengan perhitungan Equivalent (EQ) rate yang telah ditentukan oleh bank terkait, adapun data AQ rate bulan November adalah sebagai berikut :

Tabel Data Pembagian Nisbah dan EQ Rate

\begin{tabular}{|c|c|c|c|}
\hline $\begin{array}{c}\text { Jangka } \\
\text { Waktu }\end{array}$ & Bank & Nasabah & EQ Rate \\
\hline 1 Bulan & 70 & 30 & $6,80 \%$ \\
\hline $\begin{array}{c}\text { 3ulan } \\
\text { 6 Bulan }\end{array}$ & 65 & 35 & $7,93 \%$ \\
\hline
\end{tabular}




\begin{tabular}{|c|c|c|c|}
\hline 12 Bulan & 45 & 55 & $10,20 \%$ \\
\hline
\end{tabular}

Sumber: PT. BPRS Amanah Bangsa

Perhitungan bagi hasil yang didapat nasabah adalah :

$\underline{\text { Nominal } X \text { EQ rate }}=$ Bagi Hasil

\section{Bulan}

Dalam pembukaan rekening deposito biasanya dikenakan biaya-biaya kepada nasabah dengan syarat bahwa nasabah tersebut menyimpan dana minimal Rp.7,500,000,Biasanya nasabah akan dikenakan biaya berupa pajak sebesar 2,5\% dan zakat sebesar 2\%. Dalam hal ini, bank juga kurang memberikan informasi yang menjelaskan tentang adanya pemotongan biaya seperti diatas kepada nasabah.

Pembagian hasil untuk nasabah yang mempunyai saldo rekening deposito diatas Rp. 7,500,000,biasanya sudah dipotong oleh biaya yang pajak dan zakat.

Misalkan, nasabah A membuka rekening Deposito sebesar Rp.50.000.000,- dengan jangka waktu 6 bulan, maka jumlah bagi hasil yang diterima oleh nasabah adalah sebagai berikut:

$$
\begin{aligned}
& \frac{\mathrm{Rp} .50,000,000, \times \quad 9,07 \%}{12}=377,917 \\
& =377,917-2,5 \% \text { (pajak) }-2 \% \text { (zakat) } \\
& =361,099
\end{aligned}
$$

Jadi, jumlah bagi hasil yang diterima oleh nasabah A pada setiap bulan sebesar Rp. 361,099,-

\section{Promosi Produk Deposito}

Menurut KBBI, promosi adalah kegiatan komunikasi untuk meningkatkan penjualan dengan pameran, periklanan, demonstrasi dan usaha lain yang bersifat persuasif. Pada saat mahasiswa mengamati kegiatan yang berlangsung pada BPRS Amanah Bangsa, mahasiswa menemukan bahwa dalam hal mempromosikan produk Deposito tidak maksimal dilakukan seperti brosur yang tidak ditawarkan, dan letak brosur tersebut berada pada pojok meja Teller, sehingga banyak nasabah yang tidak melihat adanya brosur. Selama mahasiswa melakukan kegiatan PKL, juga pada bagian CS tidak melakukan Cross Selling kepada nasabah, sehingga nasabah tidak mengetahui adanya produk Deposito tersebut.

Menyangkut hal promosi pihak BPRS seharusnya mengganti penempatan brosur, sehingga banyak nasabah yang akan melihat brosur dan mungkin tertarik menggunakan produk Deposito. BPRS juga dapat memasang pamflet atau spanduk yang menggambarkan produk Deposito, sehingga banyak nasabah yang tahu dan tertarik. Pada bagian CS juga seharusnya melakukan Cross Selling pada saat melayani nasabahnya. Sehingga adanya peningkatan pada produk Deposito Mudharabah.

\section{KESIMPULAN}

Berdasarkan hasil dari data yang telah didapat dan pembahasan mengenai data tersebut, maka pada bagian ini penulis ingin mengemukakan kesimpualan mengenai prosedur pengelolaan deposito yaitu:

1.Aplikasi akad mudharabah dalam produk deposito pada BPRS Amanah Bangsa yakni akad yang pengelolaannya sepenuhnya menjadi tenggung jawab mudharib (bank) dan nasabah wajib mengikuti ketentuan yang diberikan oleh pihak bank.

2.Banyak keuntungan yang akan diperoleh jika menginfestasikan dana pada produk bank ini, yaitu nisbah yang besar, tidak ada pinalti yang diberikan jika pencairan dana dilakukan sebelum tanggal jatuh tempo yang telah dijanjikan, juga bagi umat muslim dapat berinfestasi sesuai syariat islam yang berlaku.

3.Pada bank keuntungan yang utama yaitu mendapatkan bagi hasil, adapun perhitungan bagi hasil pada BPRS Amanah Bangsa yaitu jumlah uang yang akan didepositokan dikali dengan EQ rate yang telah ditentukan bank dibagi dengan 12 
bulan, maka akan dapat jumlah bagi hasil yang akan diterima nasabah.

\section{REFERENSI}

[1] Adiwarman A. Karim Analisis Fiqih dan Keuangan. Jakarta: PT Rajagrafindo Persada, 2004.

[2] Adiwarman A. Karim. Analisis Fiqih dan Keuangan. Jakarta: PT Rajagrafindo Persada, 2010.

[3]. Ascarya. Akad dan Produk Bank Syariah. Jakarta: PT Rajagrafindo Persada, 2012.

[4]. Esy Nur Aisyah. "Penerapan Sistem Bagi Hasil Pada Tabungan Mudharabah Pada BMT-MMU Pasuruan". dalam Jurnal El Dinar. Malang: Fakultas Ekonomi Universitas Islam Negeri (UIN) Maliki Malang. Vol 1, No 01/Januari 2013.

[5] Hendi Suhendi. Fiqih Muamalah. Jakarta: Rajawali Pers, 2010.
[6] Heri Sudarsono. Bank dan Lembaga Keuangan Syariah Deskripsi dan Ilustrasi. Yogyakarta: Ekonisia, 2012.

[7] Husein Umar. Metode Penelitian Untuk Skripsi dan Tesis Bisnis. Jakarta: PT.

RajaGrafindo, 2009.

[8] Ismail. Perbankan Syariah. Jakarta: Kencana, 2011.

[9] Latumaerissa, R. Julius, Bank dan Lembaga Keuangan Lainnya, Salemba Empat, Jakarta, 2011.

[10] Zaini Zulkifli, Mengelola Kualitas Layanan Perbankan, PT. Gramedia Pustaka Utama, Jakarta, 2014

[11] Machmud Amir dan Rukmana, Bank Syari'ah Teori, Kebijakan dan Studi Empiris DiIndonesia, Erlangga, Jakarta, 2010

[12] POJK NOMOR 03/2016

Undang-undang No 10 Tahun 199 